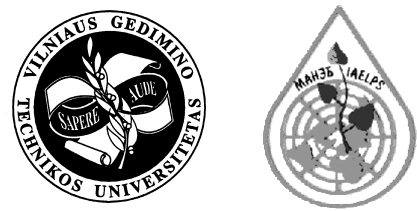

\title{
BIOLOGICAL PURIFICATION OF AIR POLLUTED WITH VOLATILE ORGANIC COMPOUNDS BY USING ACTIVE SLUDGE RECIRCULATION
}

\author{
Aušra Zigmontienė, Pranas Baltrènas \\ Dept of Environmental Protection, Vilnius Gediminas Technical University, \\ Sauletekio al. 11, LT-10223 Vilnius-40, Lithuania.E-mail: aak@ap.vtu.lt
}

Received 1 Oct 2003; accepted 12 Dec 2003

\begin{abstract}
Various methods for removal of volatile organic compounds (VOC) from the air are applied in the world. Their selection is determined by the efficiency and costs of the method. Biofiltration is a new technology to control environmental pollutants helping to regulate emissions of VOC with unpleasant odours in to the air and working environment.

When VOC are to be removed from large volumes of air, equipment of biological purification charged with active sludge is used. Such an equipment has a rather simple structure and efficiency of to 98-99\%. Active sludge as a biocharge has both a high concentration of microorganisms compared to stationary charges and good sorption features. Sorptive capacity changes when a load to active sludge is changed, and this has a negative impact on biochemical decomposition of organic substances and, at the same time, on purification efficiency. Calculation and evaluation of an optimal working mode of the equipment enable to avoid desorption of VOC in the system or to diminish it to a minimal value. In the biological air-purification equipment sorption of an organic substance on the surface of active sludge is running at the initial stage. An organic substance is decomposed biologically only in the second stage, and oxygen dissolved in the system (in the charge) is used and VOC desorption from the system is blocked. One of the main parameters determining the biological air-purification process and its intensity is change of the concentration of oxygen dissolved (CDO) in water phase and maintenance of its minimal value after termination of aeration (when the equipment is out of operation for some time). In operating equipment with a biocharge one more important problem is encountered - the lifetime of the charge and its renewal in the equipment to maintain required concentration of the active sludge.

The goal of the investigation is evaluation of purification efficiency of the equipment and the sorptive capacity of active sludge (depending on a load), selection of the working mode, uninterrupted biochemical decomposition of organic substances (based on the concentration of dissolved oxygen) when the charge is in its still state, and investigation of its biooxidating properties when a biofilter works with a biologically active charge and with an inactive charge having only sorptive properties.
\end{abstract}

Keywords: organic substances, biological air purification, active sludge, sorption load, volatile organic compound (VOC) desorption, concentration of dissolved oxygen (CDO).

\section{Introduction}

Among the most important issues today in many countries, there are the following two: rational use of natural resources and protection of the environment against pollutants of a different origin and harmful both to the environment and human beings.

Many organic substances are used in various industry branches as chemical, lacquer and paint, oil refining, food industries, and these escape into the atmosphere in various ways. Among the most widely spread ones are volatile organic compounds (VOC) rather low concentrations of which are harmful to human beings and may induce irreversible health changes to living organisms [1].
For many decades people have been looking for effective methods for neutralization of VOC, nevertheless, all of them have both advantages and limitations. Biofiltration is a new technology to control environmental pollutants helping to regulate emissions of VOC with unpleasant odours into the air and working environment.

At first, the biological purification process was used for domestic and industrial wastewater purification. Only much later the same biochemical processes were also adapted for removal of volatile organic substances and other components of an organic origin from the air. Following the same principles, the air-purification equipment with a charge of active sludge is used for purification of large volumes (10-100 thousand $\mathrm{m}^{3} / \mathrm{h}$ ) of polluted air in Germany, France, Japan and other coun- 
tries. The equipment is rather simple in design and of a small size because $1 \mathrm{~g}$ of active sludge contains around $1 \times 10^{12}-10^{14}$ of microorganisms; considerably more than that in biological or soil filters. The equipment with active sludge is installed in enterprises (e g paper, wood processing, lacquer and paint industries) where high concentrations of air-polluting organic substances are present. The efficiency of such an equipment reaches up to $98-99 \%$ [2].

Active sludge used as a biocharge in the equipment has good sorptive properties. The sorptive capacity changes when the load upon active sludge is changed and this has a negative impact on purification efficiency. Calculation and evaluation of an optimal working mode of the equipment enable to avoid desorption of VOCs in the system or to diminish it to a minimal value. In the biological air-purification equipment sorption of an organic substance at the surface of active sludge takes place at the initial stage. The organic substance is decomposed biologically only at the second stage, oxygen dissolved in the system is used and VOC desorption from the system is blocked. There are no practical investigations as for changes of the concentration of dissolved oxygen in the charge when the equipment is out of operation due to technical faults or absence of a permanent pollution supply and aeration, i e oxygen supply to the system is terminated. Such investigations are important in order to evaluate how long active sludge preserves its oxidation properties which determine the equipment efficiency, and how biooxidation rate changes in the system based on the concentration of dissolved oxygen (CDO) when the biofilter works with its full capacity. Active sludge has good sorptive properties, therefore, it is rather complicated to evaluate, whether the system is still active or it works only as a natural sorbent of VOC and biochemical processes are already terminated. Therefore, at the next investigation stage, taking active sludge and that with lost oxidation properties, it was determined how these two systems under investigation work in the presence of organic substances differing by their volatility and dissolubility in the water phase [3].

So, evaluation of the purification efficiency of the equipment and the sorptive capacity of active sludge (depending on a load), selection of working mode (based on CDO), biochemical decomposition of organic substances when the charge is in its still state (aeration is terminated) and investigation of its biooxidation properties when a filter operates with a biologically active charge and with that having only sorptive properties (inactive charge) - all that was the main investigation goal.

\section{Main principles of the biological air-purification method}

In order to have biological degradation of organic substances released into the environment from natural and industrial processes, the main factor is presence of bacteria, yeast and fungi. Biological decomposition of organic compounds under the impact of microorganisms is possible when these compounds serve as a source of energy and carbon for the latter. In the process of decomposition new microorganisms are growing, and these compounds, under the influence of oxygen, are oxidized to carbon dioxide and water [4].

The biological purification process takes place at several stages:

1. Organic substances carried by air are dissolved in the water phase.

2. The microorganisms present in the filtering substrate absorbing the organic compounds.

3 . In the water phase the microorganisms easily decompose substances absorbed, and the biomass is growing.

The final product of biological degradation: microorganisms transform synthetic chemical substances to harmless minerals and cell mass. Such a capability of microorganisms to decompose organic substances makes them very handy in air purification [5].

The same processes are in progress when removing organic pollutants from the air by using active sludge as well. This is determined by the bacteriological composition of active sludge.

Active sludge is a mixture of microbial strains (bacteria) used for biological purification of wastewater and air polluted with VOC. Active sludge, at the presence of enzymes, use pollutants (the substrate) as food and oxidizes them to carbon dioxide $\left(\mathrm{CO}_{2}\right)$, water $\left(\mathrm{H}_{2} \mathrm{O}\right)$, nitrites, nitrates, phosphates, etc. The process of biological decomposition is oxidation of organic substances, and it may be expressed as:

$$
\begin{gathered}
\text { organic pollutant }+\mathrm{O}_{2} \rightarrow \mathrm{CO}_{2}+\mathrm{H}_{2} \mathrm{O}+ \\
\text { energy }+ \text { biomass }
\end{gathered}
$$

The main role in the process of pollutant decomposition is taken by bacteria, and it is determined by different microbiologists that $1 \mathrm{~g}$ of dry substance of active sludge (DSAS) contains from $10^{8}$ to $10^{14}$ cells. Various kinds of bacteria grow during this purification process Pseudomonas, Bacillus, Bacterium, Mycobacterium, Pseudobacterium, etc. Percentage of bacteria may vary depending on the load to active sludge (amount of pollutants per $1 \mathrm{~g}$ of DSAS per day), ambient temperature, $\mathrm{pH}[6]$.

The growth rate of microorganisms present in active sludge depends, at first, on the amount of organic substances (pollutants). When pollutants are supplied periodically, microorganisms grow at the beginning because of food surplus. Microorganisms decompose pollutants and the concentration of the latter gradually goes down. The processes of pollutant oxidation in the cells of microorganisms are governed by constitutive (the main) and adaptive enzymes. Activity of fermentation depends on temperature, environmental $\mathrm{pH}$, the value of oxidation-reduction potential, the concentration of the substrate and enzymes, the concentration of substances retarding biochemical processes [7, 8].

As it may be seen from the Table, microorganisms decompose most of organic compounds. Nevertheless, 
Bacteriological composition of active sludge

\begin{tabular}{|l|l|}
\hline \multicolumn{1}{|c|}{ Microorganisms } & \multicolumn{1}{c|}{ Destruction } \\
\hline Pseudomonas & $\begin{array}{l}\text { Decomposes hydrocarbons having } \\
\text { more than one carbon atom }\end{array}$ \\
\hline Flavobacterium & $\begin{array}{l}\text { Decomposes ethane, propane and } \\
\text { other hydrocarbons having up to 8 } \\
\text { carbon atoms }\end{array}$ \\
\hline Achromobacter & Nitrogen-binding bacteria \\
\hline Sphareotilus & Decomposes organic acids \\
\hline Coli-aerogenes & Decomposes organic acids \\
\hline Alcaligenes & Oxidizes hydrogen as energy source \\
\hline Bacillus & Decomposes fatty-acids \\
\hline Comamonas & Decomposes carbon monoxide \\
\hline
\end{tabular}

the bacteriological composition of active sludge depends on the $\mathrm{pH}$-value of the substrate. When the $\mathrm{pH}$-value is low, yeast growth is more intensive. Whereas bacteria grow well when $\mathrm{pH}$ is 6-8. Such a composition of active sludge is also determined by oxygen present in the substrate.

\section{Investigation methods}

After completion of analysis of scientific literature and laboratory research work with experimental equipment for biological air purification, it has turned out that such an air-purification equipment with active sludge as the charge is suited best for air with a low concentration of VOC - up to $50 \mathrm{mg} / \mathrm{m}^{3}$. It was observed that two important factors had an impact on the equipment productivity: continuous supply of squashy and thick active sludge (its constant circulation) and selection of an optimal duration of liquid/gas contact. An important parameter determining the oxidation capacity of active sludge is the concentration of oxygen dissolved in water phase, defining the lifetime of the equipment and biooxidation rate in the system.

Taking into account all these parameters, the biological air-purification equipment with recirculation of active sludge was developed and manufactured. Its principled structure is depicted in Fig 1.

The height of the equipment is $2,2 \mathrm{~m}$. The equipment consists of a vertical Venturi tube with a confusor, the nick of the tube, a diffuser, a tank for liquid connected to the diffuser, a flat separator of drops and a protective net fastened in the upper part of the tank above the diffuser. Active sludge is supplied by means of a pump into the Venturi tube and contacts with the polluted air [9]. A blower is connected to the air-inlet nipple. The flow of air supplied is controlled by a damper. The design capacity of the equipment is $1000 \mathrm{~m}^{3} / \mathrm{h}$.

To maintain the $\mathrm{pH}$-value required $(6,8-7)$, the buffer solution of $\mathrm{NaOH}$ or phosphoric acid $\left(\mathrm{H}_{3} \mathrm{PO}_{4}\right)$ is added to the charge. $\mathrm{pH}$ of the charge is measured by means of the ' $\mathrm{pH} 538$ ' meter.

The experiments were carried out in laboratory conditions. The air flow at the inlet and outlet nipples was

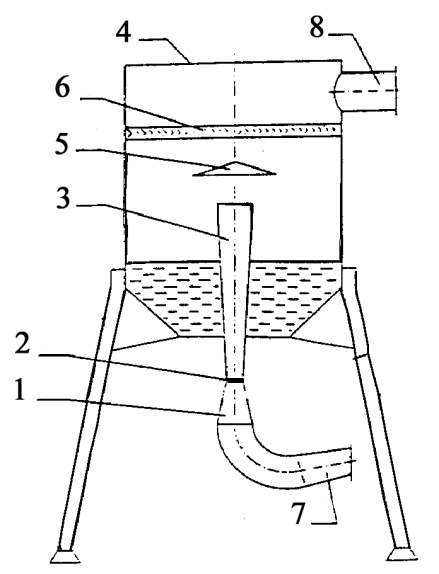

Fig 1. Principled structure of the equipment: 1 - Venturi tube with confusor, 2 - nick of the tube, 3 - diffuser, 4 tank for liquid, 5 - flat separator of drops, 6 - protective net, 7 - air-inlet nipple, 8 - air-outlet nipple

measured by means of the flowmeter TESTO-452 (Germany). During the experiment the concentration of oxygen dissolved (CDO) in active sludge was measured in $\mathrm{mg} \mathrm{O}_{2} / \mathrm{l}$. The device HI 9143 (Germany) intended for CDO measurement in pure water and wastewater was used. Measurement range in $\mathrm{mg} \mathrm{O}_{2} / 1: 0-19,99$, tolerance: $\pm 1,5 \%$. In order to determine purification efficiency, air samples were taken before and after purification. Air samples were analysed by means of the gas chromatograph “Cvet 560M".

\section{Investigation results}

At the first stage of the investigation, a study was made on dependence of the efficiency of the biological air-purification equipment on different organic substances, such as acetone, toluene, xylene and their concentrations (Figs 2, 3). As it is known, the rate of fermentation reaction and degree of decomposition of organic substances are influenced by the concentration and composition of these organic substances, concentration of the substrate, temperature and other factors.

It was determined that purification efficiency of the equipment only in a small part (up to $500 \mathrm{mg} / \mathrm{m}^{3}$ ) depends on initial concentrations of organic substances. Nevertheless, at their small amounts the purification equipment works not with full capacity and microorganisms present in the substrate start to dwindle because of the lack of food source required. When the concentration is increased - over $800 \mathrm{mg} / \mathrm{m}^{3}$ and more, the efficiency of the equipment drops down: to $65 \%$ for acetone, to $42 \%$ for xylene, to $30 \%$ for toluene. The amount of active sludge present in the biological airpurification equipment is insufficient to oxidize such concentrations of organic substances. Of course, these results were influenced by the concentration of the active sludge in the equipment as well. At $4 \mathrm{~g} / \mathrm{l}$ concentration of active sludge and high concentrations of organic 


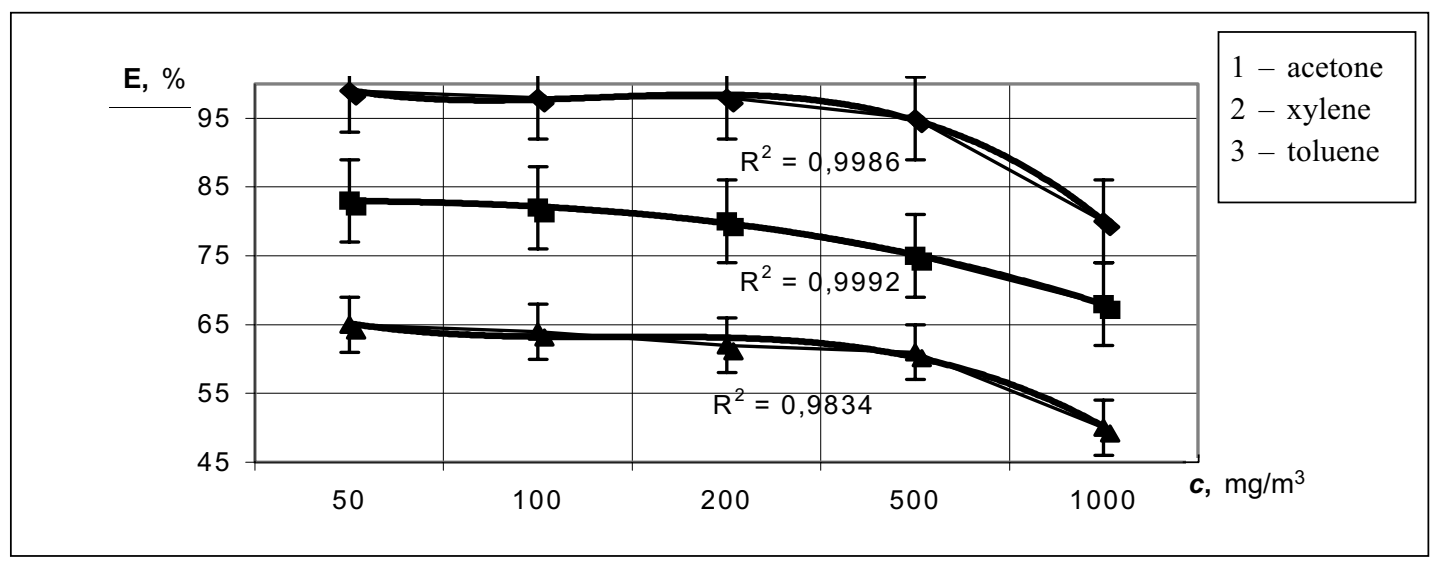

Fig 2. Equipment efficiency versus the concentration of organic substances $\left(c_{\text {active sludge }}=6,8 \mathrm{~g} / 1\right.$, amount of purified air $=300 \mathrm{~m}^{3} / \mathrm{h}$ )

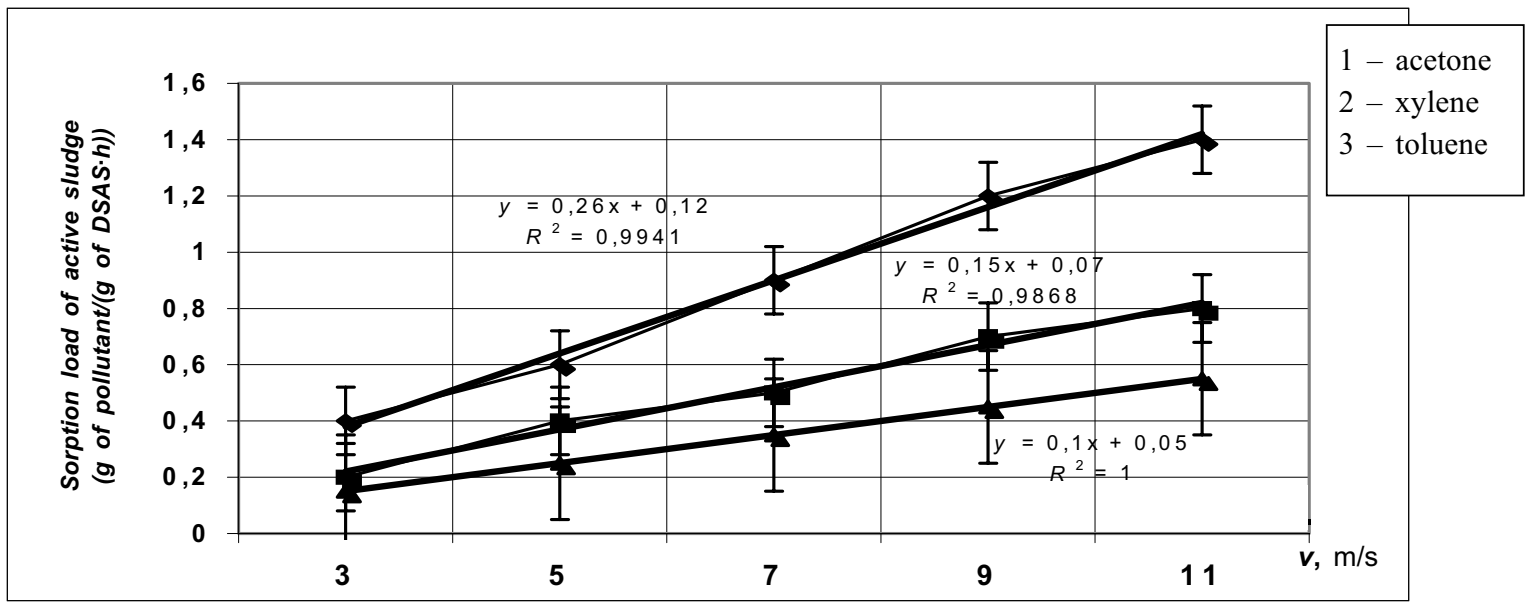

Fig 3. Sorption load of active sludge and the biooxidation rate of VOC versus air flow supplied and pollutant concentration in the equipment, $\left(c_{\text {active sludge }}=6,8 \mathrm{~g} / 1, v_{\text {charge }}=0,8 \mathrm{~m}^{3}\right)$

substances, the effect of their toxicity is displayed. The microorganisms are poisoned with organic substances, their concentration goes down and after some period the biodestruction process is fully interrupted. Due to the fact that active sludge is a good sorbent of organic substances, they are sorbed in the water phase. When the equipment operates further, a reverse process shows up: desorption of organic substances from the water phase.

In order to analyse the results obtained and evaluate the efficiency of the equipment, calculation was performed of the sorption load to active sludge (biooxidation rate) - the amount of pollutants per mass unit of active sludge per time unit:

$$
A=\frac{Q_{p} C \eta}{a_{a} V}, \mathrm{~g} \text { of pollutant } /(\mathrm{g} \text { of DSAS } \cdot \mathrm{h}),
$$

where: $Q_{p}-$ amount of purified air, $\mathrm{m}^{3} / \mathrm{h}$;

$C$ - pollutant concentration, $\mathrm{g} / \mathrm{m}^{3}$;

$h$ - pollutant absorption coefficient;

$a_{a}$ - DSAS concentration in the equipment, $\mathrm{g} / \mathrm{l}$; $V$ - working volume of the equipment, 1 .
When purifying air in heavily loaded equipment, $\mathrm{i}$ e when $1 \mathrm{~g}$ of active sludge handles 500-1000 $\mathrm{mg}$ of an organic substance, efficiency decreases. This may be explained by the fact that completeness of the growth phase of microorganisms and the state of sludge flakes depend on the load to active sludge. At high loads (9850$5000 \mathrm{mg}$ of pollutant / (g of DSAS $\cdot \mathrm{h}$ )) fine-dyspersated, slowly precipitating particles with filiform bacteria and protozoa are generated, and this has a negative impact on purification efficiency. When the equipment has a medium load (1000-100 mg of pollutant/(g of DSAS $\cdot h)$ ), the sludge is well precipitating, the flakes have a large surface area and sorb well organic substances.

Theoretical calculations carried out confirm the results of experimental investigation that the efficiency of the equipment is influenced by air flow supplied, the amount of an organic substance and concentration of active sludge in the equipment at the same time.

During experiments the concentration of oxygen dissolved in active sludge was monitored as well. At the beginning of operation of the equipment the CDO value in the equipment is always maintained at a level 
of 9-12 $\mathrm{mg} \mathrm{O}_{2} / 1$. This is a sufficient amount for biochemical processes to run. When aeration is terminated, $\mathrm{i}$ e the equipment is stopped, a rather rapid decrease of the CDO value is observed in the system. The recorded measurement data are presented in Fig 4.

When the measurements were made and the equipment stopped, it was observed that in the period of $1 \mathrm{~h}$ the $\mathrm{CDO}$ value did not decrease up to a critical value when biooxidation processes running in the system became interrupted. Nevertheless, these measurements have shown that, in order to maintain an active state of the charge in the equipment, a constant oxygen flow to the system is required maintaining the $\mathrm{CDO}$ value not less than $2 \mathrm{mg} \mathrm{O} / 1$.

As it was mentioned earlier, active sludge is a good sorbent consisting of flakes with a large surface area and capable of sorbing large amounts of pollutants. Nevertheless, the main reason to use active sludge in biopurification processes is its capability to decompose volatile organic compounds to harmless dissociation products.

In order to substantiate the biochemical pollutant- decomposition process taking place in the equipment, a parallel investigation of active sludge with lost biooxidation properties but still showing its sorptive properties in the experiment was carried out to prove sorption and biodestruction processes.

The investigation has shown that the biological airpurification equipment with a charge of active sludge retains its initial efficiency after 9 days of operation. And, on the contrary, when the equipment is charged with "dead" sludge, pollutants are sorbed, nevertheless, their desorption starts after a while, and organic substances are "released" from the sludge and the water phase. The rate of this desorption process depends on substance volatility and dissolubility in water as well.

Three different organic substances having different dissolubility and volatility were chosen for experiments. Acetone is the most volatile substance among those used for experiments. Therefore, its desorption rate is the highest. $\Delta c$ - amount of an organic substance (in $\mathrm{mg} / \mathrm{m}^{3}$ or $\%$ ) which is not decomposed by the microorganisms of active sludge during the desorption process and "escapes" back into the air. As it may be seen from Figs 5, 6 and

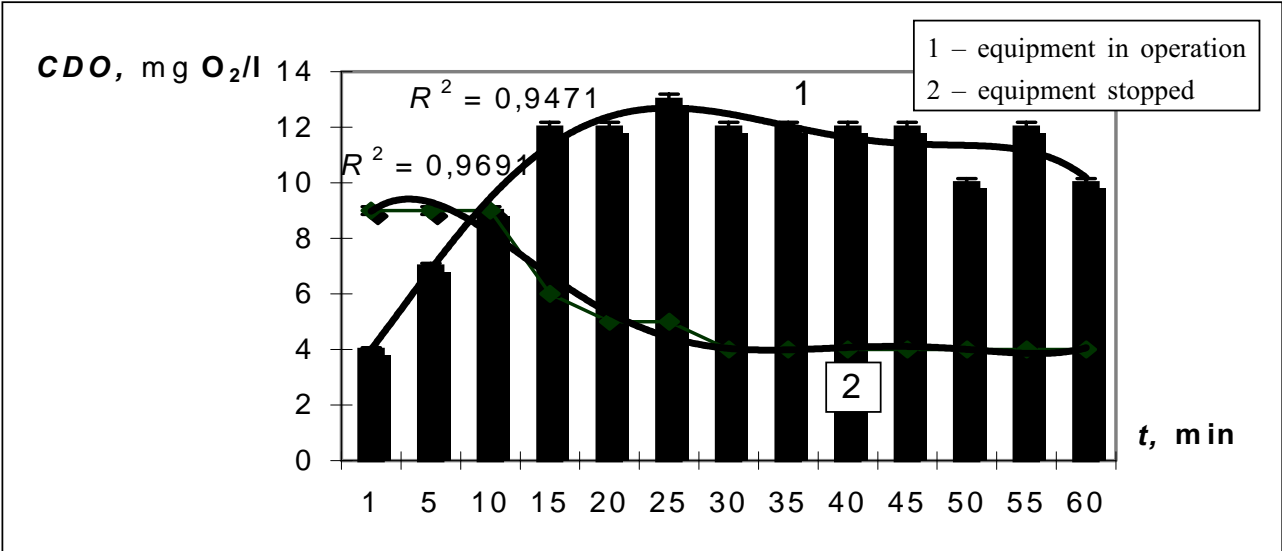

Fig 4. Rate of biooxidation of organic substances (based on CDO) in active sludge when the equipment is in operation and when aeration is terminated, $\left(c_{\text {active sludge }}=6,8 \mathrm{~g} / \mathrm{l}\right.$, amount of purified air $=300 \mathrm{~m}^{3} / \mathrm{h}$ )

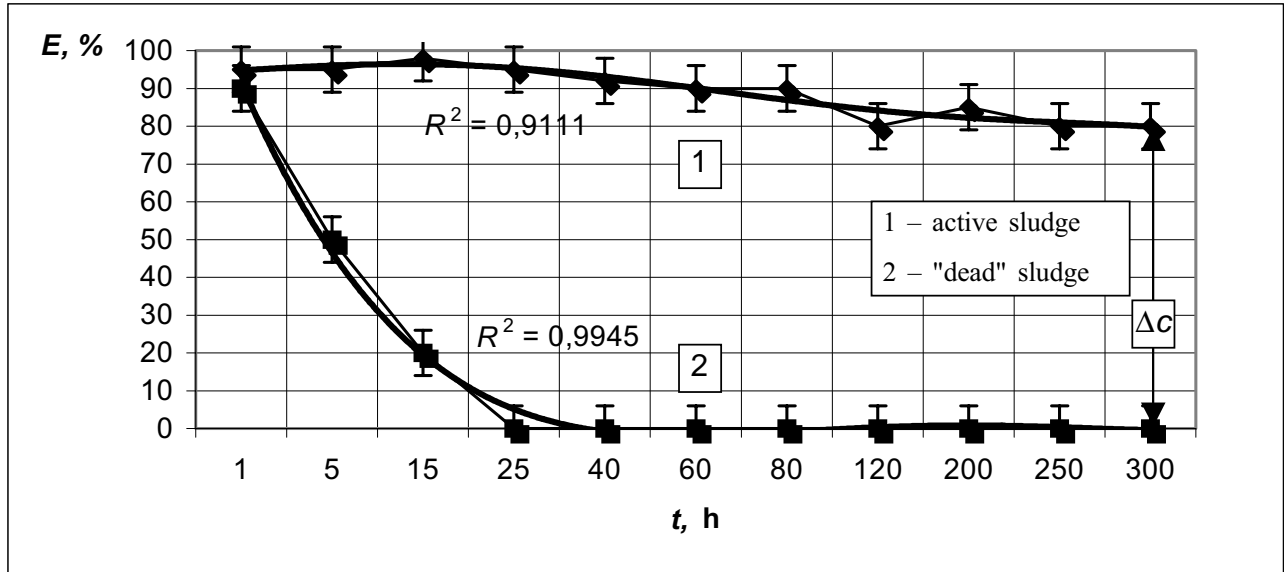

Fig 5. Time function of biooxidation and sorptive properties of active sludge and that of desorption rate versus charge state $\left(c_{\text {acetone }}=200 \mathrm{mg} / \mathrm{m}^{3} ; c_{\text {active sludge }}=9 \mathrm{~g} / \mathrm{l}\right.$, amount of purified air $\left.=300 \mathrm{~m}^{3} / \mathrm{h}\right)$ 


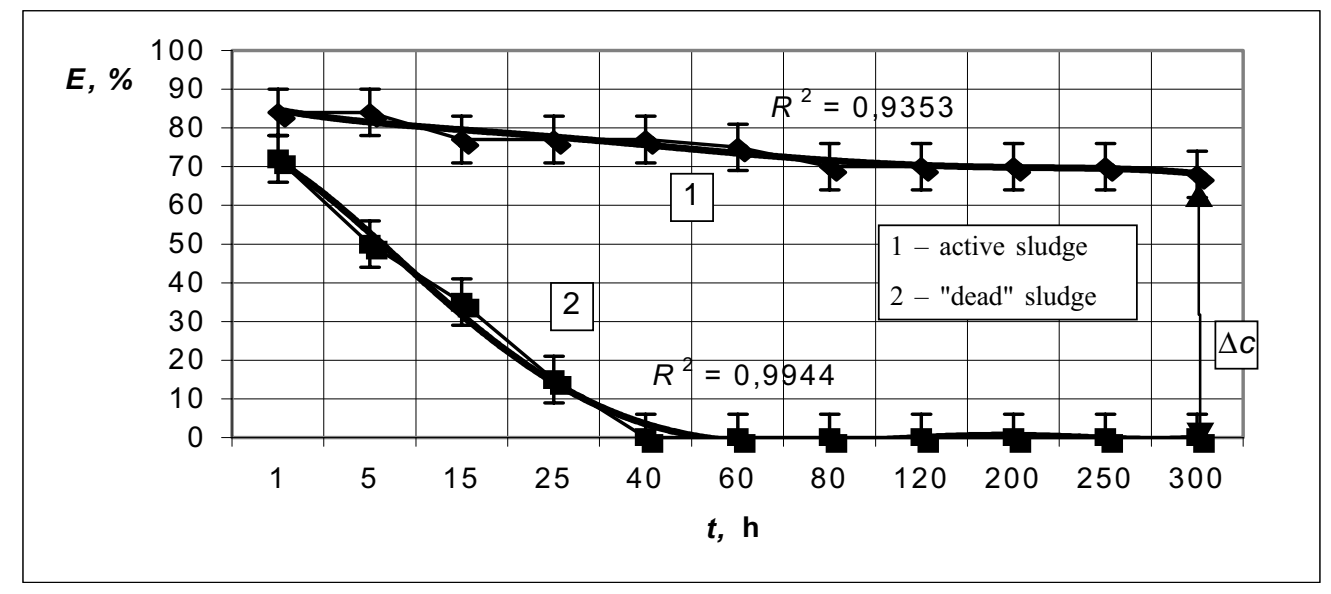

Fig 6. Time function of biooxidation and sorptive properties of active sludge and that of desorption rate versus charge state $\left(c_{\text {xylene }}=100 \mathrm{mg} / \mathrm{m}^{3} ; c_{\text {active sludge }}=9 \mathrm{~g} / \mathrm{l}\right.$, amount of purified air $\left.=300 \mathrm{~m} / \mathrm{h}\right)$

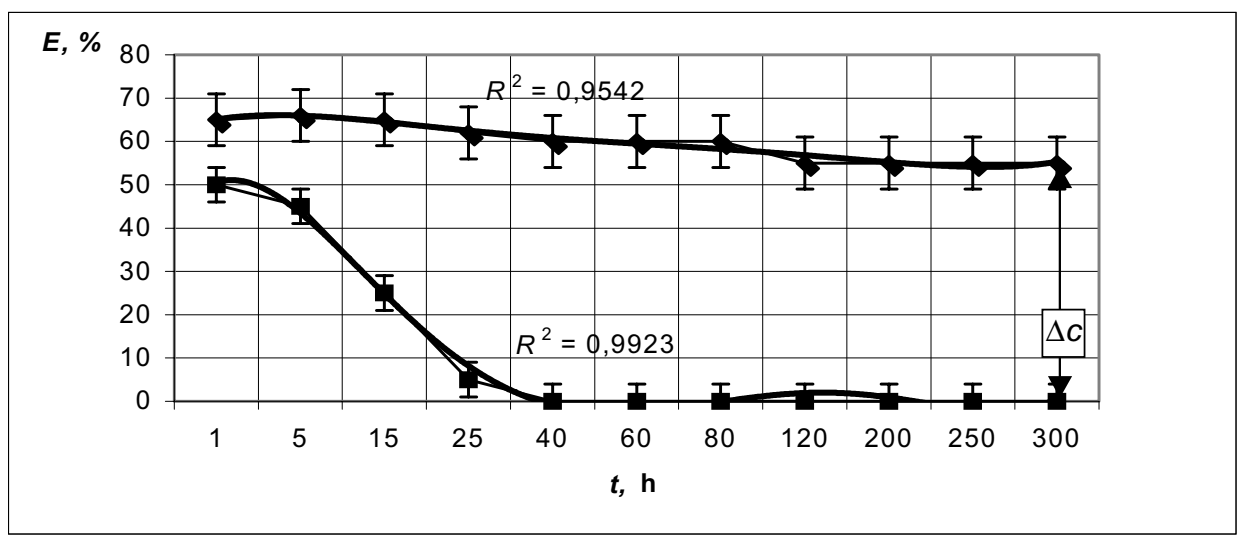

Fig 7. Time function of biooxidation and sorptive properties of active sludge and that of desorption rate versus charge state $\left(c_{\text {toluene }}=100 \mathrm{mg} / \mathrm{m}^{3} ; c_{\text {active sludge }}=9 \mathrm{~g} / \mathrm{l}\right.$, amount of purified air $\left.=300 \mathrm{~m}^{3} / \mathrm{h}\right)$

7 , the concentrations of substances investigated go down to minimal values after the same period of time -50 60 hours. Nevertheless, at the initial moment the amounts released from an inactive charge during the desorption process are different: the amount of acetone diminished by $50 \%$ after 5 hours, the amount of toluene and xylene diminished by $50 \%$ after 15 hours.

Calculation and evaluation of an optimal working mode of the equipment enable to avoid desorption of VOC in the system or diminish it to a minimal value. The experiments carried out enable to evaluate how long active sludge retains its oxidation properties (based on CDO) when a biofilter works with full capacity.

The experiment results obtained clearly prove the process of biological air purification in the equipment and its efficiency. When the biodestruction process is in progress, the number of microorganisms in active sludge also increasesl. This has a negative impact on the efficiency of the equipment. In order to remove this effect, it is needed to dilute the active sludge with water after some period of operation and to maintain its optimal concentration in the equipment. Active sludge used as a biocharge in the equipment has good sorptive properties.

\section{Conclusions}

1. The experiments performed show that the highest purification efficiency of the equipment - $95 \%$ for acetone, $75 \%$ for xylene, $60 \%$ for toluene, is reached when the ratio of the air amount supplied to the equipment and the charge amount during recirculation is the highest.

2. Active sludge used as a biocharge in the equipment has good sorptive properties. Sorptive capacity changes when a load to active sludge is changed. At high loads (9850-5000 mg of pollutant / (g of DSAS $\cdot h)$ ) fine-dyspersated, slowly precipitating particles with filiform bacteria and protozoa are generated, and this has a negative impact on purification efficiency. When the equipment has a medium load (1000-100 mg of pollutant / ( $\mathrm{g}$ of DSAS·h)), the sludge is well precipitating, the flakes have a large surface area and sorb well organic substances. Calculation and evaluation of an optimal working mode of an equipment enable to avoid the desorption of VOC in the system or diminish it to a minimal value.

3. Measurements of the concentration of dissolved 
oxygen $(\mathrm{CDO})$ in the equipment charge, when it is aerated and when the equipment is stopped, have shown that in the period of $1 \mathrm{~h}$ the $\mathrm{CDO}$ value goes down from 9-12 $\mathrm{mg} \mathrm{O}_{2} / 1$ to $5-4 \mathrm{mg} \mathrm{O} / 1$, nevertheless, it does not reach a critical value, when biooxidation processes running in the system become interrupted. Nevertheless, these measurements have shown that, in order to maintain an active state of the charge in the equipment, a constant oxygen flow to the system is required main-

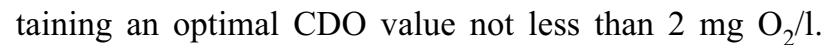

4. Investigation of active sludge and that with lost biooxidation properties show that in the case of inactive sludge in the equipment the process of VOC desorption starts in the equipment which results in decrease of the efficiency up to a critical value and in decrease of the sorption load to active sludge up to zero. The concentrations of the substances investigated went down to their minimal values after the same period of time $-50-60$ hours. Nevertheless, at the initial moment the amounts released from an inactive charge during the desorption process are different: the amount of acetone diminished by $50 \%$ after 5 hours, the amount of toluene and xylene diminished by $50 \%$ after 15 hours. It is determined that the rate of the desorption process as well as the biooxidation rate is determined by the dissolubility in the water phase and the volatility properties of VOC.

5. When purifying air by means of the equipment charged with active sludge, several important problems are encountered having an influence on the efficiency of the equipment: continuous supply of squashy and thick active sludge (constant circulation of the sludge) and selection of an optimal duration of liquid/gas contact; these problems are partly removed by the use of a recirculated charge in the equipment.

6. Experiments with organic substances show that a high efficiency of the equipment is determined by good absorption (dissolubility) of an organic substance in the water phase of active sludge, which depends on the physical properties and amount of a pollutant and on the concentration of active sludge in the equipment.

7. On the basis evaluated and calculated parameters, in order to select an optimal working mode of the equipment, the following parameters should be controlled: amounts of pollutants supplied with the air flow, intensity of active-sludge recirculation, concentration of active sludge in the equipment.

8. Summarizing all the experimental data obtained, one may state that a charge of active sludge is a promising factor for industrial high-capacity (over $10000 \mathrm{~m}^{3}$ / h) air-purification equipment.

\section{References}

1. Jakštaitè, A.; Bakas, A.; Šimaitis, R. Biological air purification using active sludge. Environmental Engineering (Aplinkos inžinerija), Vol VII, No. 3, Vilnius: Technika, 1999, p 103-108 (in Lithuanian).

2. Jakštaite, A. Application of biological air-purification method. In: Papers from the Republican Conference of Young Scientists „Environmental Engineering“. Vilnius: Technika, 1998, p 86-94.

3. Adami, Z.; Kummel, R. Zum Einsatz eines adsorptionsaktiven Trägersmaterials bei der biologischen Reinigung lossemitellhaltiger Abluft. Gefahrstoffe Reinhaltung der Luft, 1997(9), S. 365-369.

4. Kirchner, K.; Schlachter, U. Biological purification of exhaust air using fixed bacterial monocultures. Man and his Ecosystem. In: Proceedings of the $8^{\text {th }}$ World Clean Air Congress, 1989, p 367-372.

5. Deshusses Marc, A.; Hamer, G.; Dunn Irving, J. Behavior of biofilters for waste-air biotreatment. Environmental Science \& Technology (H. W. Wilson - AST), April 1995, Vol 29, p 1048-1058. ISSN 0013936X.

6. Kirchner, K.; Schlachter, U.; Gossen, C. A.; Wagner, S. Grundlagen der biologischen Abgasreinigung, Fortschritte bei der thermischen, katalytischen, sorptiven und biologischen Abgasreinigung, VDI Verlag, 1993. $630 \mathrm{~S}$.

7. Ivanian, S. Y.; Voloshina, O. S. Cleaning of gas emissions by using biological method (Очистка газовых выбросов биологическим методом). Moscow: VNIPIEIlesprom, 1986. 36 p (in Russian).

8. Gethke, H. G. Positive und negative Erfahrungen mit großtechnischen Biofilteranlage. VDI Verlag, 1993. $630 \mathrm{~S}$.

9. Bakas, A.; Baltrènas, P.; Jakštaitè, A. Biological air-purification equipment, LR patent No 4798, May 25, 2001.

\section{ORO, UŽTERŠTO LAKIAISIAIS ORGANINIAIS JUNGINIAIS, BIOLOGINIS VALYMAS, TAIKANT AKTYVIOJO DUMBLO RECIRKULIACIJĄ}

\section{A. Zigmontienè, P. Baltrènas}

\section{S antrauka}

Pasaulyje plačiai taikomi įvairūs ore esančių LOJ valymo metodai. Pasirinkimą lemia metodo efektyvumas ir pigumas. Biofiltracija - tai nauja aplinkos teršalų kontrolès technologija, padedanti reguliuoti nemalonaus kvapo lakiujų organinių junginiu (LOJ) emisijas ị atmosferą ir darbo aplinkos ore.

Dideliems oro, užteršto lakiaisiais organiniais junginiais, kiekiams valyti taikomi biologinio valymo irenginiai, kuriuose kaip įkrova naudojamas aktyvusis dumblas. Tokie įrenginiai esti nesudetingos konstrukcijos, jų efektyvumas - 98-99\%. Aktyviajam dumblui, naudojamam kaip bioikrova įrenginyje, būdinga ne tik didelè mikroorganizmų koncentracija, palyginti su nuostoviosiomis ikkrovomis, bet ir geros sorbcinès savybès. Vienas iš pagrindinių parametrų, lemiančiu biologini oro valymo procesą ir jo intensyvuma, - ištirpusio deguonies koncentracijos (IDK) vandeninejje fazeje kitimas ir palaikoma minimali jos reikšmė nutraukus aeraciją (irenginiui nedirbant tam tikrą laiko tarpa). Eksploatuojant įrenginius su bioikrova, susiduriama ir dar su viena svarbia problema - ¿krovos ilgaamžiškumu ir būtinumu ją atnaujinti reikiamai aktyviojo dumblo koncentracijai irenginyje palaikyti.

Tyrimu tikslas - ivertinti valymo irenginių efektyvuma, aktyviojo dumblo sorbcinę talpą (priklausomai nuo apkrovos) ir parinkti veikimo režimą, kad nepertraukiamai vyktu biocheminis organinių medžiagų skaidymas (pagal ištirpusio deguonies 
koncentracija), ikrovai esant ramybès būsenos, bei biooksidacinių savybių tyrimai, biofiltrui veikiant su biologiškai aktyvia ir tik sorbciniu savybių (neaktyvia) turinčia ikkrova.

Raktažodžiai: organiniai junginiai, biologinis oro valymas, aktyvusis dumblas, sorbcine apkrova, LOJ desorbcija, ištirpusio deguonies koncentracija.

\section{БИОЛОГИЧЕСКАЯ ОЧИСТКА ВОЗДУХА ОТ ЛЕТУЧИХ ОРГАНИЧЕСКИХ ВЕЩЕСТВ С ПОМОЩЬЮ РЕЦИРКУЛЯЦИИ АКТИВНОГО ИЛА}

\section{А. Зигмонтене, П. Балтренас}

Р езю ме

В настоящее время первостепенное значение приобрели проблемы рационального использования природных ресурсов и охраны окружающей среды от загрязнений выбросами промышленных предприятий. Разрабатываемые в настоящее время методы очистки газов имеют как преимущества, так и недостатки при применении к конкретным источникам выбросов. Они, как правило, односторонне переводят токсичные соединения в менее токсичные с большим значением ПДК, поглощая газообразное вещество жидкой фазой или образуя высококонцентрированный регенерат. Среди газообразных соединений немало летучих органических веществ (ЛОВ), которые выделяются на предприятиях химической, нефтяной промышленности. Для очистки воздуха от ЛОВ в настоящее время применяется немало разных методов.

Биологический метод, применяемый для очистки ЛОВ, довольно прост в конструктивном отношении, достаточно эффективен, а также легко контролируем.

Биологическая очистка воздуха от летучих органических веществ происходит в несколько этапов. Прежде всего органическое вещество абсорбируется в водяной фазе активного ила. Затем микроорганизмы разлагают органическое вещество путём биохимического окисления.

При исследовании процесса абсорбции в лабораторных условиях был смонтирован фильтр - абсорбер, в который для аэрации подаётся загрязнённый ацетоном, ксилолом и толуолом воздух. В качестве микробиологически активного компонента используется водная суспенсия активного ила.

Ключевые слова: органические соединения, биологическая очистка воздуха, активный ил, сорбционная ёмкость, десорбция ЛОВ, концентрация растворённого кислорода. 